\title{
Relationship of Parental Abuse on Anxiety, Depression, Aggression, Self-esteem, and Smartphone Overindulgence in Elementary Students
}

\section{부모의 학대가 초등학생의 불안, 우울, 공격성, 자존감, 스마트폰 과몰입에 미치는 영향}

Sun-a Jung ${ }^{1}$, Eun-sil Kim² ${ }^{2}$, Jin-sub Jung ${ }^{3}$ 정선아 ${ }^{1}$, 김은실 ${ }^{2}$, 정진섭 ${ }^{3}$

${ }^{1}$ Student, Child Welfare, NamSeoul University, Korea, Mieri93@naver.com

${ }^{2}$ Professor, Child Welfare, NamSeoul University, Korea, gender@hanmail.net

${ }^{3}$ Student, ChildWelfare, NamSeoul University, Korea,bom6101@hanmail.net

Corresponding author: Eun-sil Kim

\begin{abstract}
The purpose of this study is to find out whether parental abuse affects elementary school students' anxiety, depression, aggression, self-esteem, and smartphone overindulgence, and to find out what factors affect them most. This study has been conducted based on self-reporting questionnaires collected from elementary school students who are in between 4th and 6th grades throughout the Seoul, Gyeonggi, and South Chungcheong Provinces and used correlation and multiple regression to check the demographic characteristics of subjects surveyed through frequency analysis using SPSS for Win.24.0 The results of this study have shown that parental physical abuse, emotional abuse, and neglect have affected elementary school students' anxiety, depression, aggression, self-esteem, and smartphone overindulgence, and therefore have had enough meaningness as a prior study, on which various therapeutic and preventive programs have been develpoed. The limitation of this study are that there are no significant results for sexual abuse, so subsequent studies have been required for the further study of children with sexual abuse.
\end{abstract}

Keywords: Abuse, Anxiety, Depression, Aggression, Self-esteem, Smartphone Overindulgence

요약: 본 연구의 목적은 부모의 학대가 초등학생의 불안, 우울, 공격성, 자존감, 스마트폰 과몰입에 대해 영향을 미치는지를 알아보고 어떤 요인에 가장 영향을 주는지에 대해 알아보기 위함이다. 본 연구는 서울, 경기, 충남권 초등학생 4 6학년을 대상으로 자기보고 방식의 설문지를 수집하고 SPSS for Win. 24.0 통계프로그램을 이용하여 빈도분석을 통한 조사대상의 인구학적 특성과 변인 간의 상관관계 확인을 위해 상관분석과 다중회귀분석을 사용하였다. 본 연구의 결과는 부모의 신체적 학대, 정서적 학대, 방임이 초등학생의 불안, 우울, 공격성, 자존감, 스마트폰 과몰입에 영향을 미치는 것으로 나타났으며, 본 연구의 결과에 따라 다양한 치료 및 예방 프로그램 개발의 필요성에 근거가 될 수 있는 선행연구로서

*이 논문은 제 1 저자 정선아의 남서울대학교 석사학위논문 축약본임.

Received: December 16, 2020; $1^{\text {st }}$ Review Result: January 28, 2021; $2^{\text {nd }}$ Review Result: March 20, 2021

Accepted: April 30, 2021 
의의가 있다. 본 연구의 제한점은 성적학대에 대해 유의미한 결과가 나타나지 않았다는 점에서 후속 연구에서는 성적학대 아동에 대한 연구가 필요하다.

핵심어: 학대, 불안, 우울, 공격성, 자존감, 스마트폰 과몰입

\section{1. 서론}

아동학대는 보호자를 포함한 성인이 아동의 건강 또는 복지를 해치거나 정상적 발달을 저해할 수 있는 신체적-정신적·성적 폭력이나 가혹행위를 하는 것과 아동의 보호자가 아동을 유기하거나 방임하는 것을 말한다(법제처, 2014)[1]. 최근 아동 학대현황에 따르 면, 부모에 의한 아동학대는 전체의 $76.8 \%(17,177$ 건)로 가장 높으며, 아동학대 사례 10 건 중 약 7건 정도가 부모에 의해 발생되고, 2001년부터 2017년도까지 아동인구는 꾸준히 감 소하는 반면 인구대비 아동학대사례 비율은 꾸준히 증가한 것으로 나타났다(보건복지부, 2017)[2].

아동이 성장해가면서 긍정적 정서와 부정적 정서를 모두 경험하게 되는 것은 자연스러 운 현상이지만 부모의 학대는 아동기의 우울에 영향을 미치고 우울이 신체화 증상까지 연결되며, 만성우울로까지 연결되게 된다(박준성, 2019)[3]. 아동기의 학대경험이 있는 성 인은 그렇지 않은 성인보다 스트레스로 인한 우울증을 발병하게 하는 취약요인인 특성불 안이 높아지게 되는데, 아동기의 학대 경험이 불안의 위험인자로 작용하게 된다는 근거 가 된다(경미하, 2013)[4]. 뿐만 아니라 부모의 학대를 받은 아동은 부모의 행동에 대한 모 델링을 통해 다른 아동을 괴롭히고 때리는 등의 공격적인 양상을 많이 보이는 것으로 알 려져 있다(김혜성, 박수경, 김혜련, 2006; 신혜영, 2003; 조유정, 석주영, 박인전, 2005)[5-7]. 자존감 또한 부모와 같은 중요한 타인들과의 상호작용 속에서 반영되는 자신에 대한 평 가를 통해 발달해가므로(Rosenberg, 1979)[8], 부모로부터의 부정적 학대경험은 아동의 자 아존중감 형성에 손상을 주게 되어(우수정, 2017)[9] 학대 경험이 있는 아동은 학대 경험 이 없는 아동에 비해 자존감이 유의미하게 낮으며, 낮은 자존감은 또래관계에까지 악영 향을 미친다(우수정, 2017; 정익중, 2008)[9][10]. 부모의 양육 태도는 최근 심각성이 대두되 고 있는 스마트폰 과몰입에도 직·간접적으로 영향을 준다(김대명, 조준수, 2015)[11]. 우 울이 높으면 부정적 정서를 제거하기 위해 스마트폰에 더욱 과몰입하게 되어(김재엽,황현 주, 2016)[12], 신체적 증상(시력저하, 두통, 어깨통증)과 심리정서적인 발달(우울과 불안, 공격성, 위축, 주의집중력 저하, 부정적 자아개념)의 문제뿐만 아니라 성인기에 이르기까 지 계속적으로 부정적인 영향을 미쳐 결국에는 성인기우울 또는 약물남용 등에 대한 문 제가 연결될 수 있다(김병년, 2013; 신성철, 백석기, 2015; 장여옥, 조남억, 2014)[13-15].

여러 선행연구에서 부모의 학대가 불안, 우울, 공격성, 자존감, 스마트폰 과몰입에 영향 을 주고 있다고 보고되고 있어 이에 본 연구의 목적은 부모의 학대가 아동의 불안, 우울, 공격성, 스마트폰 과몰입에 미치는 영향에 관하여 알아보고 아동의 특성과 어떤 관련이 있는지, 불안, 우울, 공격성, 자존감, 스마트폰 과몰입 중 어떤 것에 더 영향을 미치는가 를 알아보고자 다음과 같은 연구 문제를 설정하였다.

연구문제 1. 대상자의 일반적 특성에 따른 초등학생의 불안, 우울, 공격성, 자존감, 스 마트폰 과몰입의 차이는 어떠한가? 
연구문제 2. 부모의 학대가 초등학생의 불안, 우울, 공격성, 자존감, 스마트폰 과몰입에 미치는 영향은 어떠한가?

연구문제 3. 부모의 학대는 불안, 우울, 공격성, 자존감, 스마트폰 과몰입 중 어떤 것에 더 영향을 미치는가?

\section{2. 연구방법}

\section{1 연구대상}

본 연구의 대상자는 충청, 경기, 서울, 인천 지역 초등학교 4-6학년으로 학대경험이 있 는 아동을 대상으로 모집하여 설문지를 작성 후 회수하고, 총 311 부 중 불성실한 자료를 제외하고 281부(남자 146부, 여자 135부)로 진행하였다.

\section{2 연구절차}

본 연구는 연구대상 선정을 위해 2019년 7월부터 서울, 경기, 인천, 충청권의 초등학교, 지역아동센터, 보육시설에 유선으로 연구목적에 대한 안내 후 동의를 받아 8 월 말부터 9 월말까지 약 1 개월 동안 설문지를 실시하였다.

\section{3. 연구도구}

\section{1 학대 척도 (Child Abuse Self Report Scale, CASRS)}

부모의 학대를 측정하기 위하여 Mohammadkhani 등의 CASRS 척도를 사용하였다. 이 검사도구는 신체적 학대(8문항), 정서적 학대(14문항), 방임(11문항), 성적 학대(5문항)로 4 개의 하위영역으로 구성되어있다. 문항의 형식은 ‘전혀 없음’ (1점)부터 ‘항상’ (4점)까 지 4점 척도로 되어있으며, 본 연구에서는 신체적 학대의 경우 0.829 , 정서적 학대 0.909 , 방임 0.866 , 마지막으로 성적학대는 0.869 의 신뢰도를 보여 전체 신뢰도는 .923으로 본 검 사도구는 신뢰할 수 있다.

\section{2 불안 척도 (Beck Anxiety Inventory, BAI)}

아동의 불안 정도를 측정하기 위해 Beck의 불안척도를 육성필과 김중술(1997)이 번안한 $\mathrm{BAI}$ 척도를 사용하였다. $\mathrm{BAI}$ 는 21 개의 질문으로 구성되어있으며 0 에서 3 점까지로 점수가 매겨진다. 점수가 높을수록 심각한 불안증세가 나타나며 표준화된 점수는 0-9점(최소에서 정상), 10-18점(평균에서 중간), 19-29점(중간에서 심각), 20-63점(심각)으로 나뉜다. 본 연구 에서 신뢰도는 0.913 이다.

\section{3 우울 척도 (CDI-2)}

아동의 우울 심각성을 측정하기 위해 Kovacs와 Staff(2011)의 CDI-2를 김지혜와 동료들 (2017)이 번안한 K-CDI 2 를 사용하였다. 3 가지의 문장 중에서 자신과 가장 가까운 문장을 
선택하는 형식의 3점 척도이며, 총 28 문항으로 구성되고 점수가 높을수록 우울감이 높다 고 볼 수 있다. 본 연구에서의 신뢰도는 0.924 이다.

\section{4 공격성 척도}

본 연구에서는 아동의 공격성 정도를 파악하기 위해 이은아(2011)가 개발한 '초등학생 용 공격성 척도, 를 사용하였다. 행동적 공격성(16문항), 분노감(6문항), 적대감(8문항)으 로 총 30 문항으로, ‘전혀 그렇지않다' 부터 '매우 그렇다' 까지 5점 척도로 구성되 었다. 본 척도에서는 행동적 공격성(1-16문항, 총 16개), 적대감(17-24문항, 총 8 개), 분노 감(25-30문항, 총 6 개)으로 3 개의 하위요인으로 구분된다. 본 연구에서의 신뢰도는 0.949 로 높은 신뢰도를 보였다.

\section{5 자존감 척도}

본 연구에서 아동의 자존감의 정도를 측정하기 위해서 Rosenberg의 자아존중감 검사를 사용하였다. 문항수는 총 10 문항으로 구성되었으며 4점 척도이지만, 본 연구에서는 아동 의 자존감의 정도를 좀 더 구체적으로 알아보기 위해 전문가의 조언 및 타당도 검증을 통해 ‘전혀 그렇지 않다' 부터 '매우 그렇다' 까지로 5점 척도로 진행되었다. 본 연구 에서의 신뢰도는 0.926 점이다.

\section{6 스마트폰 과몰입 척도}

본 연구에서는 아동의 스마트폰 과몰입 정도를 측정하기 위해 고성자(2012)가 개발한 '초등학생용 휴대전화 의존성 진단척도' 를 사용하며, 총 20 문항으로 구성되었다. 하위 요인은 생활장애(7개 문항), 의존(3개 문항), 금단(6개 문항), 강박(4개 문항)이다. 각 문항 은 '전혀 그렇지 않다.' 부터 '매우 그렇다.' 로 5점 척도 문항이다. 점수가 커질수록 휴대전화 의존 정도는 큰 것을 의미한다. 본 연구에서의 신뢰도는 0.944 로 매우 높은 신 뢰도를 보였다.

\section{4. 분석 방법}

수집된 자료 총 281 부를 통계프로그램인 SPSS for Win. 24.0을 사용하여 Cronbach's $\alpha$ 값 을 구해 측정도구의 신뢰도를 구한 뒤 조사대상자의 일반적 특성을 살펴보기 위하여 빈 도분석을 실시하였다. 조사대상자의 일반적 특성에 따른 부모의 학대, 불안, 우울, 공격 성, 자존감, 스마트폰 과몰입 차이를 살펴보기 위하여 평균과 표준편차를 구하고, $\mathrm{t}$-검정 및 ANOVA분석을 실시하였으며, Scheff's 사후검증을 실시하였다.

조사대상자 부모의 학대, 불안, 우울, 공격성, 자존감, 스마트폰 과몰입 간의 상관관계 를 살펴보기 위하여, 상관 분석을 실시하고, 조사대상자 부모의 학대 중 4 가지 하위유형 인 정서적 학대, 신체적 학대, 방임, 성적 학대가 불안, 우울, 공격성, 자존감, 스마트폰 과몰입 각각에 미치는 영향을 살펴보기 위하여 다중회귀분석을 실시하였다. 이상과 같은 분석은 모두 유의수준 $\mathrm{p}<.05, \mathrm{p}<.01, \mathrm{p}<.001$ 에서 검증하였다. 


\section{5. 연구 결과}

\section{1 일반적특성에 따른 불안, 우울, 공격성, 자존감, 스마트폰과몰입의 차이}

본 연구 조사대상 아동의 부모의 학대, 불안, 우울, 공격성, 자존감, 스마트폰 과몰입 특성을 살펴보기 위하여 평균과 표준편차를 구하였다. 결과는 [표 1]과 같다. 부모의 학대 는 4점 척도로 평균 1.47 점으로 낮게 나타났으며, 하위요인별로는 방임이 평균 2.09점으 로 가장 높았으며, 다음으로 정서적 학대 평균 1.49 점, 신체적 학대 평균 1.25 점, 성적학 대 평균 1.02 점의 순으로 나타났다. 불안은 '전혀 느끼지 않았다' 가 0점부터 '심하게 느꼈다, 3점까지 4점 척도로 0.33점으로 낮게 나타났으며, 우울은 3점 척도로 평균 1.51 점으로 보통정도로 나타났다. 공격성은 5점 척도로 평균 1.76 점으로 낮게 나타났으며, 자 존감은 5점 척도로 평균 3.30점으로 보통정도로 나타났다. 한편 스마트폰 과몰입은 5점 척도로 평균 2.31점으로 보통이하로 나타났다.

[표 1] 부모의 학대, 불안, 우울, 공격성, 자존감, 스마트폰 과몰입 특성

[Table 1] Parents' Abuse, Anxiety, Depression, Aggression, Self-esteem, Smartphone Overindulgence Characteristics

\begin{tabular}{c|c|c|c|c|c}
\hline & 구분 & 최소값 & 최대값 & 평균 & 표준편차 \\
\hline \hline \multirow{4}{*}{ 부모의 학대 } & 정서적학대 & 1.00 & 3.21 & 1.49 & .48 \\
\cline { 2 - 6 } & 방임 & 1.00 & 3.82 & 2.09 & .62 \\
\cline { 2 - 6 } & 신체적학대 & 1.00 & 2.86 & 1.25 & .37 \\
\cline { 2 - 6 } & 성적학대 & 1.00 & 2.80 & 1.02 & .15 \\
\cline { 2 - 6 } & 학대전체 & 1.00 & 2.63 & 1.47 & .31 \\
\hline & 불안 & 0.00 & 1.90 & 0.33 & .38 \\
\hline & 우울 & 1.00 & 2.61 & 1.51 & .37 \\
\hline & 공격성 & 1.00 & 3.55 & 1.76 & .64 \\
\hline & 자존감 & 1.20 & 5.00 & 3.30 & .97 \\
\hline 스마트폰과몰입 & 1.00 & 4.45 & 2.31 & .82 \\
\hline
\end{tabular}

\subsection{1 성별에 따른 부모의 학대, 불안, 우울, 공격성, 자존감, 스마트폰 과몰입 차이}

본 연구에서는 [표 2]와 같이 조사대상 아동의 성별에 따라 부모의 학대, 불안, 우울, 공격성, 자존감, 스마트폰 과몰입에 차이가 있는지를 살펴보기 위하여 t-test를 실시하였다. 분석결과, 공격성 $(\mathrm{t}=.2 .260, \mathrm{p}<.05)$ 에서는 통계적으로 유의미한 차이를 보였으나, 부모의 학대 전체 $(\mathrm{t}=1.395, \mathrm{p}>.05)$, 불안 $(\mathrm{t}=-.275, \mathrm{p}>.05)$, 우울 $(\mathrm{t}=.226, \mathrm{p}>.05)$, 자존감 $(\mathrm{t}=-.146, \mathrm{p}<.05)$, 스마트폰 과몰입 $(\mathrm{t}=1.477, \mathrm{p}>.05)$ 은 통계적으로 유의미한 차이가 없는 것으로 나타났다. 공격성에서만 남자가 평균 1.84 점, 여자가 평균 1.67 점으로 남자가 여자보다 다소 높은 것으로 나타나 유의미한 차이를 보였다. 
Relationship of Parental Abuse on Anxiety, Depression, Aggression, Self-esteem, and Smartphone Overindulgence in Elementary Students

[표 2] 성별에 따른 부모의 학대, 불안, 우울, 공격성, 자존감, 스마트폰 과몰입 특성 차이

[Table 2] Gender-specific Differences in Parental Abuse, Anxiety, Depression, Aggression, Self-esteem, Smartphone Over-indulgence Characteristics

\begin{tabular}{|c|c|c|c|c|c|c|c|}
\hline \multicolumn{3}{|c|}{ 구분 } & $\mathrm{N}$ & 평균(M) & 표준편차(SD) & $\mathrm{t}$ & $\mathrm{p}$ \\
\hline \multirow{10}{*}{$\begin{array}{l}\text { 부모 } \\
\text { 학대 }\end{array}$} & \multirow{2}{*}{ 정서적 학대 } & 남 & 146 & 1.49 & .47 & \multirow{2}{*}{-.115} & \multirow{2}{*}{.908} \\
\hline & & 여 & 135 & 1.50 & .49 & & \\
\hline & \multirow{2}{*}{ 방임 } & 남 & 146 & 2.15 & .62 & \multirow{2}{*}{1.721} & \multirow{2}{*}{.086} \\
\hline & & 여 & 135 & 2.03 & .61 & & \\
\hline & \multirow{2}{*}{ 신체적 학대 } & 남 & 146 & 1.30 & .40 & \multirow{2}{*}{1.933} & \multirow{2}{*}{.054} \\
\hline & & 여 & 135 & 1.21 & .33 & & \\
\hline & \multirow{2}{*}{ 성적학대 } & 남 & 146 & 1.02 & .17 & \multirow{2}{*}{.061} & \multirow{2}{*}{.951} \\
\hline & & 여 & 135 & 1.02 & .11 & & \\
\hline & \multirow{2}{*}{ 전체 } & 남 & 146 & 1.49 & .31 & \multirow{2}{*}{1.395} & \multirow{2}{*}{.164} \\
\hline & & 여 & 135 & 1.44 & .31 & & \\
\hline \multirow{2}{*}{\multicolumn{2}{|c|}{ 불안 }} & 남 & 146 & 0.32 & .40 & \multirow{2}{*}{-.275} & \multirow{2}{*}{.783} \\
\hline & & 여 & 135 & 0.33 & .36 & & \\
\hline \multirow{2}{*}{\multicolumn{2}{|c|}{ 우울 }} & 남 & 146 & 1.52 & .36 & \multirow{2}{*}{.226} & \multirow{2}{*}{.821} \\
\hline & & 여 & 135 & 1.51 & .37 & & \\
\hline \multirow{2}{*}{\multicolumn{2}{|c|}{ 공격성 }} & 남 & 146 & 1.84 & .69 & \multirow{2}{*}{2.260} & \multirow{2}{*}{.025} \\
\hline & & 여 & 135 & 1.67 & .57 & & \\
\hline \multirow{2}{*}{\multicolumn{2}{|c|}{ 자존감 }} & 남 & 146 & 3.29 & .99 & \multirow{2}{*}{-.146} & \multirow{2}{*}{.884} \\
\hline & & 여 & 135 & 3.31 & .95 & & \\
\hline \multirow{2}{*}{\multicolumn{2}{|c|}{ 스마트폰 과몰입 }} & 남 & 146 & 2.38 & .85 & \multirow{2}{*}{1.477} & \multirow{2}{*}{.141} \\
\hline & & 여 & 135 & 2.24 & .78 & & \\
\hline
\end{tabular}

$$
* \overline{\mathrm{p}<.05}
$$

\subsection{2 부모의 학력에 따른 부모의 학대, 불안, 우울, 공격성, 자존감, 스마트폰 과몰입 차이}

부모의 학력에 따라 부모의 학대, 불안, 우울, 공격성, 자존감, 스마트폰 과몰입에 차이가 있는지를 살펴보기 위하여 일원분산분석(ANOVA)를 실시하였다. 분석결과는 [표 3]과 같다. 부모의 학대 전체 $(\mathrm{F}=3.878, \mathrm{p}<.05)$ 와 하위요인인 신체적 학대 $(\mathrm{F}=6.027, \mathrm{p}<.01)$, 성적학대 $(\mathrm{F}=7.254, \mathrm{p}<.01)$, 불안 $(\mathrm{F}=4.430, \mathrm{p}<.05)$ 은 통계적으로 유의미한 차이가 있는 것으로 나타났으나, 정서적 학대 $(\mathrm{F}=.160, \mathrm{p}>.05)$, 방임 $(\mathrm{F}=2.558, \mathrm{p}>.05)$, 우울 $(\mathrm{F}=2.100, \mathrm{p}>.05)$, 공격성 $(\mathrm{F}=.726, \mathrm{p}>.05)$, 자존감 $(\mathrm{F}=.284, \mathrm{p}>.05)$, 스마트폰 과몰입 $(\mathrm{F}=1.047, \mathrm{p}>.05)$ 은 통계적으로 유의미한 차이가 없는 것으로 나타났다. 
[표 3] 부모의 학력에 따른 부모의 학대, 불안, 우울, 공격성, 자존감, 스마트폰 과몰입 특성 차이

[Table 3] Differences in Parental Abuse, Anxiety, Depression, Aggression, Self-esteem, and Smartphone Overindulgence Characteristics based on Parents' Educational Background

\begin{tabular}{|c|c|c|c|c|c|c|c|c|}
\hline \multicolumn{3}{|c|}{ 구분 } & $\mathrm{N}$ & M & SD & $\mathrm{F}$ & $\mathrm{p}$ & 사후 검증 \\
\hline \multirow{15}{*}{$\begin{array}{l}\text { 부모 } \\
\text { 학대 }\end{array}$} & \multirow{3}{*}{$\begin{array}{c}\text { 정서적 } \\
\text { 학대 }\end{array}$} & 대졸 & 169 & 1.49 & .469 & \multirow{3}{*}{.160} & \multirow{3}{*}{.852} & \\
\hline & & 고졸 & 99 & 1.49 & .493 & & & \\
\hline & & 중졸 이하 & 13 & 1.57 & .528 & & & \\
\hline & \multirow{3}{*}{ 방임 } & 대졸 & 169 & 2.06 & .614 & \multirow{3}{*}{2.558} & \multirow{3}{*}{.079} & \\
\hline & & 고졸 & 99 & 2.10 & .627 & & & \\
\hline & & 중졸 이하 & 13 & 2.46 & .544 & & & \\
\hline & \multirow{3}{*}{$\begin{array}{c}\text { 신체적 } \\
\text { 학대 }\end{array}$} & 대졸(a) & 169 & 1.25 & .366 & \multirow{3}{*}{6.027} & \multirow{3}{*}{$.003 * *$} & \multirow{3}{*}{$\mathrm{c}>\mathrm{a}, \mathrm{b}$} \\
\hline & & 고졸(b) & 99 & 1.23 & .325 & & & \\
\hline & & 중졸 이하(c) & 13 & 1.59 & .568 & & & \\
\hline & \multirow{3}{*}{$\begin{array}{l}\text { 성적 } \\
\text { 학대 }\end{array}$} & 대졸(a) & 169 & 1.02 & .100 & \multirow{3}{*}{7.254} & \multirow{3}{*}{$.001 * *$} & \multirow{3}{*}{$c>a, b$} \\
\hline & & 고졸(b) & 99 & 1.01 & .102 & & & \\
\hline & & 중졸 이하(c) & 13 & 1.17 & .496 & & & \\
\hline & \multirow{3}{*}{ 전체 } & 대졸(a) & 169 & 1.45 & .293 & \multirow{3}{*}{3.878} & \multirow{3}{*}{$.022 *$} & \multirow{3}{*}{$\mathrm{c}>\mathrm{a}, \mathrm{b}$} \\
\hline & & 고졸(b) & 99 & 1.46 & .315 & & & \\
\hline & & 중졸 이하(c) & 13 & 1.70 & .405 & & & \\
\hline \multirow{3}{*}{\multicolumn{2}{|c|}{ 불안 }} & 대졸 & 169 & 0.31 & .331 & \multirow{3}{*}{4.430} & \multirow{3}{*}{$.013^{*}$} & \multirow{3}{*}{$\mathrm{c}>\mathrm{a}, \mathrm{b}$} \\
\hline & & 고졸 & 99 & 0.31 & .406 & & & \\
\hline & & 중졸 이하 & 13 & 0.63 & .657 & & & \\
\hline \multirow{3}{*}{\multicolumn{2}{|c|}{ 우울 }} & 대졸 & 169 & 1.49 & .343 & \multirow{3}{*}{2.100} & \multirow{3}{*}{.124} & \\
\hline & & 고졸 & 99 & 1.54 & .389 & & & \\
\hline & & 중졸 이하 & 13 & 1.69 & .454 & & & \\
\hline \multirow{3}{*}{\multicolumn{2}{|c|}{ 공격성 }} & 대졸 & 169 & 1.74 & .622 & \multirow{3}{*}{.726} & & \\
\hline & & 고졸 & 99 & 1.76 & .658 & & .485 & \\
\hline & & 중졸 이하 & 13 & 1.96 & .821 & & & \\
\hline & & 대졸 & 169 & 3.32 & .940 & & & \\
\hline & 자존감 & 고졸 & 99 & 3.29 & 1.023 & .284 & .753 & \\
\hline & & 중졸 이하 & 13 & 3.11 & 1.027 & & & \\
\hline & & 대졸 & 281 & 3.30 & .971 & & & \\
\hline 스마 & 트폰 과몰입 & 고졸 & 169 & 2.37 & .824 & 1.047 & .352 & \\
\hline & & 중졸 이하 & 99 & 2.23 & .819 & & & \\
\hline
\end{tabular}

\section{2 부모의 학대가 불안, 우울, 공격성, 자존감, 스마트폰 과몰입에 미치는 영향}

본 연구의 변인간 상관관계를 알기위해 pearson 상관분석하였다. 결과는 [표 4]와 같다. 
Relationship of Parental Abuse on Anxiety, Depression, Aggression, Self-esteem, and Smartphone Overindulgence in Elementary Students

부모의 학대는 불안(r=.580, $\mathrm{p}<.001)$, 우울 $(\mathrm{r}=.693, \mathrm{p}<.001)$, 공격성 $(\mathrm{r}=.512, \mathrm{p}<.001)$, 스마트폰 과몰입 $(\mathrm{r}=.488, \mathrm{p}<.001)$ 과 정 $(+)$ 의 상관관계를, 자존감 $(\mathrm{r}=-.660, \mathrm{p}<.001)$ 과 부(-)의 상관관계를 나타냈다.

[표 4] 부모의 학대, 불안, 우울, 공격성, 자존감, 스마트폰 과몰입 간의 상관관계

[Table 4] Correlation between Parental Abuse, Anxiety, Depression, Aggression, Self-esteem, and Smartphone Overindulgence

\begin{tabular}{|c|c|c|c|c|c|c|c|c|c|c|}
\hline & \multicolumn{5}{|c|}{ 부모의 학대 } & \multirow{2}{*}{ 불안 } & \multirow{2}{*}{ 우울 } & \multirow{2}{*}{ 공격성 } & \multirow{2}{*}{ 자존감 } & \multirow{2}{*}{ 스마트폰과몰입 } \\
\hline & 정서적학대 & 방임 & 신체적학대 & 성적학대 & 전체 & & & & & \\
\hline $\begin{array}{l}\text { 정서적 } \\
\text { 학대 }\end{array}$ & 1 & & & & & & & & & \\
\hline 방임 & $.566^{* * *}$ & 1 & & & & & & & & \\
\hline $\begin{array}{l}\text { 신체적 } \\
\text { 학대 }\end{array}$ & $.486^{* * *}$ & $.456^{* * *}$ & 1 & & & & & & & \\
\hline 성적학대 & .101 & .092 & $.178 * *$ & 1 & & & & & & \\
\hline 학대전체 & $.826^{* * *}$ & $.865^{* * *}$ & $.735^{* * *}$ & $.256^{* * *}$ & 1 & & & & & \\
\hline 불안 & $.454 * * *$ & $.427 * * *$ & $.570 * *$ & $.181 * *$ & $.580^{* * *}$ & 1 & & & & \\
\hline 우울 & $.583 * * *$ & $.603 * * *$ & $.528 * *$ & .086 & $.693 * * *$ & $.664^{* * *}$ & 1 & & & \\
\hline 공격성 & $.431 * * *$ & $.422 * * *$ & $.410 * *$ & .113 & $.512 * * *$ & $.416^{* * *}$ & $.484 * * *$ & 1 & & \\
\hline 자존감 & $-.568 * * *$ & $-.627 * * *$ & $-.413^{* *}$ & -.032 & $-.660 * * *$ & $-.453 * * *$ & $-.730 * * *$ & $-.490 * * *$ & 1 & \\
\hline $\begin{array}{c}\text { 스마트폰 } \\
\text { 과몰입 }\end{array}$ & $.454 * * *$ & $.423 * * *$ & $.334 * *$ & .016 & $.488^{* * *}$ & $.388^{* * *}$ & $.480 * * *$ & $.480 * * *$ & $-.501 * * *$ & 1 \\
\hline
\end{tabular}

5.3 부모의 학대가 불안, 우울, 공격성, 자존감, 스마트폰 과몰입에 미치는 영향력의 크기비교

본 연구에서는 부모의 학대가 불안, 우울, 공격성, 자존감, 스마트폰 과몰입 중 어떤 것에 더 영향을 미치는지를 살펴보기 위하여 앞에서의 다중회귀분석 결과를 비교하였는데, 다음 [표 5]와 같다. 먼저 부모의 학대의 정서적 학대는 자존감에 $\beta$ $=-.289(\mathrm{p}<.001)$ 로 가장 큰 영향을 미치는 것으로 나타났으며, 다음으로 스마트폰 과몰입 $(\beta$ $=.283, \mathrm{p}<.001)$, 우울 $(\beta=.275, \mathrm{p}<.001)$, 공격성 $(\beta=.210, \mathrm{p}<.01)$, 불안 $(\beta=.169, \mathrm{p}<.01)$ 의 순으로 영향을 미치는 것으로 나타났다. 방임은 자존감에 $\beta=-.429(\mathrm{p}<.001)$ 로 가장 큰 영향을 미치는 것으로 나타났으며, 다음으로 우울 $(\beta=.338, \mathrm{p}<.001)$, 스마트폰 과몰입( $\beta$ $=.219, \mathrm{p}<.01)$, 공격성 $(\beta=.205, \mathrm{p}<.01)$, 불안 $(\beta=.137, \mathrm{p}<.05)$ 의 순으로 영향을 미치는 것으로 나타났다.

신체적 학대는 불안에 $\beta=.411(\mathrm{p}<.001)$ 로 가장 큰 영향을 미치는 것으로 나타났으며, 다음으로 우울 $(\beta=.243, \mathrm{p}<.001)$, 공격성 $(\beta=.207, \mathrm{p}<.01)$ 의 순으로 영향을 미치는 것으로 나타났다. 한편 성적학대는 불안과 우울, 공격성, 자존감, 스마트폰 과몰입에 모두 영향을 미치지 않았다. 
[표 5] 부모의 학대가 불안, 우울, 공격성, 자존감, 스마트폰 과몰입에 미치는 영향력의 크기비교

[Table 5] Comparison of the Magnitude of Parents' Abuse on Anxiety, Depression, Aggression, SelfEsteem, and Smartphone Overindulgence

\begin{tabular}{c|c|c|c|c|c}
\hline 구분 & 불안 $(\beta)$ & 우울 $(\beta)$ & 공격성 $(\beta)$ & 자존감 $(\beta)$ & 스마트폰과몰입 $(\beta)$ \\
\hline \hline 정서적 학대 & $.169^{* *}$ & $.275^{* * *}$ & $.210^{* *}$ & $-.289^{* * *}$ & $.283^{* * *}$ \\
\hline 방임 & $.137^{*}$ & $.338^{* * *}$ & $.205^{* *}$ & $-.429^{* * *}$ & $.219^{* *}$ \\
\hline 신체적 학대 & $.411^{* * *}$ & $.243^{* * *}$ & $.207^{* *}$ & -.086 & .106 \\
\hline 성적학대 & .079 & -.016 & .036 & .052 & -.052 \\
\hline
\end{tabular}

${ }^{*} \mathrm{p}<.05, * * \mathrm{p}<.01, * * * \mathrm{p}<.001$

\section{6. 결론}

본 연구는 부모의 학대가 초등학생의 불안, 우울, 공격성, 자존감, 스마트폰 과몰입에 미치는 영향에 대해 알아보고자 자기보고식 설문지를 진행하였다.

본 연구문제에 따른 논의 및 결론은 다음과 같다.

성별에 따른 차이는 불안, 우울, 자존감, 스마트폰 과몰입에 유의미하지 않은 차이지만 공격성만 남자가 여자보다 높게 나타났다. 이는 김재철과 최지영(2010)[16] 과 일치하는 결과로 중졸이하의 부모가 고졸과 대졸에 비해 유의미하게 높다는 선행연구(박덕숙, 2002)[17] 와도 일치하는 결과이다.

부모의 학대가 초등학생의 불안, 우울, 공격성, 자존감, 스마트폰 과몰입에 미치는 영향 은 부모의 학대를 경험한 아동일수록 초등학생의 불안, 우울, 공격성, 스마트폰 과몰입이 높게 나타났다. 반대로 부모의 학대를 경험한 아동일수록 자존감은 낮게 나타났다. 학대 의 하위유형인 불안, 우울, 공격성의 경우 정서적 학대와 신체적 학대, 방임이 영향을 미쳤지만 성적학대는 영향을 미치지 않았다. 자존감과 스마트폰 과몰입의 경우 정서적 학대와 방임은 영향을 미쳤지만 신체적 학대와 성적 학대는 영향을 미치지 않았다. 성적 학대가 불안, 우울, 공격성, 자존감, 스마트폰 과몰입에 유의미하지 않은 결과가 나타난 것은 가해자가 가족이나 가까운 사람의 경우 아동이 알리는 것에 대해 두려움을 느끼거 나 성행위의 의미자체를 잘 이해하지 못하거나 아동이 성적 학대를 당한 것인지 인지하 지 못하는 경우 의미있는 결과가 나타나지 않는다는 박미숙(2010)[18]의 연구를 참고할 수 있다.

부모의 학대가 가장 영향을 미치는 것은 학대의 하위요인별로 상이한 결과가 나타났 는데 정서적 학대는 자존감> 스마트폰 과몰입> 우울> 공격성> 불안의 순서로 영향을 미 치는 것으로 나타났다. 방임도 가장 크게 영향을 미치는 것이 자존감으로 나타났으며 그 다음으로는 우울, 스마트폰 과몰입, 공격성, 불안 순서로 영향을 미치는 것으로 나타 났다. 신체적 학대는 불안에 가장 큰 영향을 미치고, 그 다음으로는 우울, 공격성 순서로 영향을 미쳤다. 성적학대는 불안과 우울, 공격성, 자존감, 스마트폰 과몰입에 모두 유의미 한 영향을 미치지 않은 것으로 나타났다. 
본 연구의 의의는 첫째, 부모의 정서적 학대와 방임을 경험한 아동은 자존감이 유의미 하게 낮아지며, 이는 우울과 스마트폰 과몰입에 영향을 미칠 수 있다. 따라서 치료적 차 원에서 학대경험이 있는 아동에게 자존감향상프로그램과 스마트폰 중독 예방 및 치료프 로그램이 필요하다는 근거가 되는 연구로서 의의가 있다. 둘째, 부모의 학대에 대한 인구 학적 특성에서 부모의 학력에 따른 차이가 나타났다. 따라서 예방적 차원에서는 예비부 모를 대상으로 아동의 행동에 대한 훈육방법과 발달단계별 필요한 양육법 등에 대한 예 비부모교육프로그램의 개발에 대한 선행연구로서 의의가 있다. 셋째, 부모의 방임을 경험 한 아동은 불안, 우울, 공격성, 자존감, 휴대폰 과몰입에 모두 영향을 미친다. 따라서 학 교와 지역기관에서 돌봄교실 혹은 방과후 프로그램 등에 대해 다차원적으로 지원이 필요 하다는 것을 알 수 있는 선행연구로서 의의가 있다.

본 연구의 제한점은 다음과 같다.

연구결과에서 성적 학대 경험 아동에 대한 결과가 유의미하지 않게 나타났는데, 사전 에 부모의 동의를 구한 초등학생 아동을 대상으로 연구가 진행되었기 때문에 학대를 행 하는 부모가 있더라도 연구에 참여하지 않거나 진실하게 보고하지 않을 수 있는 자기보 고식 설문의 제한이 존재하여 정확한 자료를 수집하고 일반화하기 어려운 부분이 있다. 이에 후속연구로 성적 학대를 경험한 아동을 대상으로 불안, 우울, 공격성, 자존감, 스마 트폰 과몰입에 미치는 영향에 대한 연구가 필요하다. 또한 부모의 학력에서 중졸 이하인 경우 고졸과 대졸에 비해 유의미하게 학대의 가능성이 높은 것으로 나타났기 때문에 학 대의 심각성 및 중요성에 대한 부모교육이 아동의 불안, 우울, 공격성, 자존감, 스마트폰 과몰입에 영향이 나타나는지 알아보는 연구가 필요하다.

\section{References}

[1] https://www.law.go.kr/ The Legislative Office, Article 37, Oct 1, (2020)

[2] http://www.mohw.go.kr/react/gm/sgm0701vw.jsp./ 2017 National child abuse report, (2019)

[3] Joon-sung Park, Jung-min Ahn, Tae-yeon Jung, A study of the effects of parental persistent abuse on depression and somatic symptoms in children, Social Sciences Research, (2019), Vol.31, No.2, pp.107-134.

[4] Miha Kyoung, Jung-Ah Min, Jeong-Ho Chae, Relationship of Affective Symptoms and Resilience with Childhood Abuse in Patients with Depressive or Anxiety Disorders, Anxiety and Mood, (2013), Vol.9, No.1, pp.68-73.

[5] Hye-sung Kim, Soo-kyung Park, Hye-ryeon Kim, A Study on the Development of Substance Abuse Relapse Prevention for Female Adolescent Shelter Residents, Alcohol and Health Behavior Research, (2006), Vol.7, No.1, pp.39-52.

[6] Hye-young Shin, Experience of Abuse from Parents and Relationship between Aggression and Interpersonal Anxiety: Focusing on Senior Elementary School Children, Sogang University, Master's Thesis, (2003)

[7] Yoo-jung Cho, Joo-young Seok, In-jeon Park, The Effects of Child Abuse on Children from Their Parents on SelfControl and Aggressive Behavior of Adolescents : Differences between Ordinary and Delinquent Adolescents, Studies on Korean Youth, (2005), Vol.16, No.1, pp,133-163.

[8] M. Rosenberg, Society and adolescentself-image, Pinceton, NJ: Princeton University Press, (1965)

[9] Su-jung Woo, The Effects of Parental Abuse and Neglect, and Children's Peer Attachment, on Mobile Phone Dependency, Family and Environment Research, (2013), Vol.51, No.6, pp.583-590.

[10] Ik-jung Jung, Developmental Pathways from Child Abuse to Peer Rejection, Korean Journal of Child Studies, (2008), Vol.29, No.4, pp.79-95. 
[11] Dae-myung Kim, Jun-soo Cho, Mediating Effect of Anxiety and Depression on the Relationship between Perceived Father and Mother Rearing Attitude and Smartphone Addiction, The Journal of Educational Research, (2015), Vol.13, No.2, pp,153-172, UCI : G704-SER000010453.2015.13.2.004

[12] Jae-yeop Kim, Hyun-joo Hwang, The Effects of Child Abuse on Adolescents' Smartphone Addiction - Focusing on the Mediating Effects of Depression and Gender Differences -, Journal of the Korean society of child welfare, (2016), Vol.53, pp.105-133, UCI : G704-000946.2016..53.005

[13] Byung-nyun Kim, A mediating effect of depression in the relationship between self-control and smartphone addiction among college students, Korean Journal of Family Welfare, (2013), Vol.39, pp.49-81, DOI : $10.16975 / \mathrm{kjfsw} .2013 . .39 .002$

[14] Sung-chul Shin, Seok-ki Baek, Focusing on the effect of regulating flexibility in relation to the excessive use of smartphones and school violence by early adolescents, Korea Society of Police Research Conference, (2015), August 7-8; Mok-Po, Korea.

[15] Yeo-ok Jang, Nam-eok Cho, Effects of smartphone addiction on youth problematic behavior: focusing on teenagers in Gyeonggi-do, Journal of Future Oriented Youth Society, (2014), Vol.11, No.2, pp.137-156.

[16] Jae-chul Kim, Ji-young Choi, Effects of parental abuse on the aggression of and children: focusing on the mediating effects of self-esteem and school violence victimization, Journal of the Korea Welfare Panel Conference, (2010), September 17, Seoul, Korea.

[17] Deok-sook Park, The relationship between parental abuse and anxiety, aggression and school adaptation, Dongduk Women's University Graduate School, Master's Thesis, (2002)

[18] Mi-sook Park, Problems and countermeasures in protecting victims of child sexual violence, The Justice, (2010), Vol.115, pp.22-39. 